\title{
Analisis Keterkontrolan Model Penyebaran Virus Polio Tipe Vaccine-Derived Polio Virus (VDPV) dan Wild Polio Virus (WPV)
}

\author{
Sari Cahyaningtias ${ }^{1 *}$, Rani Kurnia Putri ${ }^{2}$ \\ ${ }^{1,2}$ Universitas PGRI Adi Buana Surabaya, sari@unipasby.ac.id
}

\begin{abstract}
Administering vaccines is important as an effort to eradicate polio which is spread by polio virus through physical contact from person to person and exacerbated by an unhealthy sanitation environment. Giving this vaccine does not mean without side effects, administering an oral vaccine (OPV) without proper calculation causes the person given the vaccine to be contract the virus, the truth is, vaccine contains a weakened virus. Therefore, control in administering vaccines is important to do.The polio virus is transmitted to people with weak immune systems and poor sanitation environment, called WPV (Wild Polio Virus). Another impact that is feared from giving OPV is the occurrence of Vaccine Derrived Polio Virus (VDPV), a condition in which the polio virus mutates to become malignant and gives rise to a new type of polio virus. In this study, the mathematical model of the polio virus distribution was formed into a system of non-linear dynamic equations which then carried out a control analysis of the dynamic system of distribution polio by establishing the vaccination rate as the control of the system. The results of the control analysis show that the system can be controlled with the control variables given, namely (1) the level of vaccination of vulnerable children; (2) vaccination rates of vulnerable children without vaccines.
\end{abstract}

Keywords: equilibrium point, control, vaccination level, polio type VDPV and WPV

\begin{abstract}
Abstrak, Pemberian vaksin penting dilakukan sebagai upaya pemberantasan penyakit polio yang disebarkan oleh virus polio melalui kontak fisik dari orang ke orang dan diperparah dengan lingkungan sanitasi yang tidak sehat. Pemberian vaksin ini bukan berarti tanpa efek samping, pemberian dosis vaksin oral (OPV) tanpa perhitungan yang tepat menyebabkan orang yang diberi vaksin dapat terjangkit virus tersebut, karena sejatinya, vaksin berisikan virus yang telah dilemahkan. Oleh sebab itu, kontrol dalam pemberian vaksin, penting untuk dilakukan. Virus polio yang menular ke orang dengan daya tahan tubuh lemah dan lingkungan sanitasi yang buruk, disebut dengan WPV (Wild Polio Virus). Dampak lain yang dikhawatirkan dari pemberian OPV adalah terjadinya Vaccine Derrived Polio Virus (VDPV) yaitu suatu keadaan dimana virus polio bermutasi menjadi ganas dan menimbulkan virus polio tipe baru. Pada penelitian ini, model matematika dari persebaran virus polio ini dibentuk kedalam system persamaan dinamik tak linier yang kemudian dilakukan analisis keterkontrolan dari sistem dinamik persebaran polio tersebut dengan menetapkan tingkat vaksinasi sebagai control dari sistem. Hasil analisis keterkontrolan menunjukkan bahwa system dapat dikontrol dengan variabel kendali yang diberikan, yaitu (1) tingkat vaksinasi anak-anak rentan; (2) tingkat vaksinasi anak-anak rentan tanpa vaksin.
\end{abstract}

Keywords: titik kesetimbangan, keterkontrolan, tingkat vaksinasi, polio tipe VDPV dan WPV 


\section{Pendahuluan}

Polio merupakan penyakit menular yang menyerang otak, melumpuhkan sistem syaraf dan berpotensi menyebabkan kematian. Penyebaran virus polio terjadi melalui kontak fisik orang ke orang yang diperburuk dengan lingkungan yang memiliki sanitasi yang buruk. Sampai saat ini penyakit polio belum ditemukan obatnya, akan tetapi ada vaksin yang aman dan efektif. Oleh sebab itu strategi pemberantasan polio didasarkan pada pencegahan infeksi dengan memberikan imunisasi untuk setiap batita (Balita dibawah tiga tahun) secara bertahap untuk menghentikan penularan. Terdapat dua tipe vaksin yang diberikan, yaitu OPV (Oral Polio Vaksin) atau vaksin yang diberikan melalui tetes mulut dan IPV (Injection Polio Vaksin) atau vaksin yang diberikan melalu suntikan. Sampai saat ini, di beberapa daerah di Indonesia, pencegahan penyakit polio dilakukan dengan melaksanakan imunisasi polio menggunakan Oral Vaksin Polio (OPV) yang berisi poliovirus yang sudah dilemahkan. Selain sebagai tindakan pencegahan tertular virus polio dari penderita yang tanpa gejala, OPV juga berguna untuk membersihkan virus polio liar yang ada didalam usus secara serempak. Kewaspadaan terhadap penyebaran polio ini harus tetap dijaga, karena orang yang sudah terjangkit, namun tidak terlihat gejala penyakitnya dapat menularkan virus ke orang yang sehat.

Berdasarkan pada permasalahan diatas, pemberian vaksin sangat penting untuk dilakukan, namun bukan berarti hal tersebut tidak memiliki efek samping. Sehingga kontrol pada pemberian vaksin polio perlu diperhatikan dengan jelas, karena pemberian OPV pada batita yang memiliki daya tahan tubuh lemah justru dapat terinfeksi oleh virus yang telah dilemahkan tersebut, karena pada prinsipnya virus tersebut hanya dilemahkan dan tidak dimatikan, maka virus dapat keluar melalui feses. Sehingga ada kemungkinan virus tersebut menular ke orang lain yang juga memiliki daya tahan tubuh lemah dan lingkungan sanitasi yang buruk, hal ini disebut juga dengan WPV (Wild Polio Virus). Dampak lain yang dikhawatirkan dari pemberian OPV adalah terjadinya Vaccine Derrived Polio Virus (VDPV) yaitu suatu keadaan dimana virus polio bermutasi menjadi ganas dan menimbulkan virus polio tipe baru.

Pada penelitian kali ini, akan dilakukan kontrol terhadap terjadinya transmisi virus polio akibat dari pemberian vaksin melalui oral (OPV) yaitu terjadinya WPV dan VDPV, dengan cara melakukan analisis stabilitas transmisi virus polio akibat dari pemberian OPV. Selanjutnya dilakukan pengendalian penyebaran virus melalui pemberian vaksin secara bertahap untuk setiap klasifikasi umur menggunakan pontryagin's minimum principle Dan hasil perhitungan akan disimulasikan menggunakan software Matlab 2012.

\section{Metode Penelitian}

Pembentukan model matematika dari transimi virus polio membentuk sistem dinamik tak linear. Dasar dari pembentukan model ini adalah mengklasifikasikan total populasi individu menjadi beberapa kelompok utama. Total populasi anakanak pada saat ke $t$ dinotasikan sebagai $N(t)$. Populasi ini terbagi menjadi beberapa kategori, yaitu: $S(t)$ adalah anak-anak rentan tanpa vaksin; $V(t)$ adalah anak-anak rentan penyakit yang menerima vaksin OVP; $S_{m}(t)$ anak-anak rentan penyakit tanpa vaksin (tidak menerima vaksin) OVP; $E_{w}(t)$ anak-anak yang 
terpapar virus WPV; $E_{v}(t)$ anak-anak yang terpapar virus VDPV; $I_{w}(t)$ anakanak yang terinfeksi virus WPV; $I_{v}(t)$ anak-anak yang terinfeksi virus VDPV; $R$ adalah anak-anak yang telah sembuh; $L_{w}(t)$ anak-anak yang mengalami kelumpuhan akibat virus WPV; $L_{v}(t)$ anak-anak yang mengalami kelumpuhan akibat virus VDPV; secara matematis dapat ditulis sebagai

$$
N(t)=S+V+S_{m}+E_{W}+E_{V}+I_{W}+I_{v}+R+L_{W}+L_{V}
$$

Model matematika dari persebaran virus polio tipe WPV dan VDPV pada anak-anak dapat diformulasikan sebagai berikut (Okuonghae dkk, 2015)

$$
\begin{aligned}
& \frac{d S}{d t}=(1-f) \Lambda-\beta_{w} S \frac{I_{w}}{N}-\beta_{v} S \frac{I_{v}}{N}-\alpha S-\mu S \\
& \frac{d V}{d t}=f \Lambda+r \alpha S+\emptyset S_{m}-\rho V-\mu V \\
& \frac{d S_{m}}{d t}=(1-r) \alpha S-\emptyset S_{m}-\xi_{v} \beta_{v} S_{m} \frac{I_{v}}{N}-\xi_{w} \beta_{w} S_{m} \frac{I_{w}}{N}-\mu S_{m} \\
& \frac{d E_{w}}{d t}=S\left(\beta_{w} \frac{I_{w}}{N}+q \beta_{v} \frac{I_{v}}{N}\right)-S_{m}\left(\xi_{w} \beta_{w} \frac{I_{w}}{N}-q \xi_{v} \beta_{v} \frac{I_{v}}{N}\right)-\sigma_{w} E_{w}-\mu E_{w} \\
& \frac{d E_{v}}{d t}=(1-q) S \beta_{v} \frac{I_{v}}{N}-(1-q) S_{m} \xi_{v} \beta_{v} \frac{I_{v}}{N}-\sigma_{v} E_{v}-\mu E_{v} \\
& \frac{d I_{w}}{d t}=\sigma_{w} E_{w}-\psi_{w} I_{w}-\kappa_{w} I_{w}-\mu I_{w}-\delta_{w} I_{w} \\
& \frac{d I_{v}}{d t}=\sigma_{v} E_{v}-\psi_{v} I_{v}-\kappa_{v} I_{v}-\mu I_{v}-\delta_{v} I_{v} \\
& \frac{d R}{d t}=\rho V-\psi_{w} I_{w}-\psi_{v} I_{v}-\mu R \\
& \frac{d L_{w}}{d t}=\kappa_{w} I_{w}-\mu L_{w} \\
& \frac{d L_{v}}{d t}=\kappa_{v} I_{v}-\mu L_{v}
\end{aligned}
$$

Tabel 1. Deskripsi Variabel dan Parameter Model

\begin{tabular}{cl}
\hline Variabel & Interpretasi \\
\hline$S$ & Populasi anak-anak rentan virus tanpa vaksinasi \\
$V$ & Populasi anak-anak rentan polio dengan tervaksin \\
$S_{m}$ & Populasi anak-anak rentan yang tidak diberi OPV vaksin \\
$E_{w}\left(E_{v}\right)$ & Populasi anak-anak yang terinfeksi virus tipe WPV (VDPV) \\
$I_{w}\left(I_{v}\right)$ & Populasi anak-anak terinfeksi \\
$R$ & Populasi anak-anak sembuh dari virus polio \\
$L_{w}\left(L_{v}\right)$ & Populasi anak-anak lumpuh karena infeksi WPV (VDPV) \\
$\alpha(t)$ & Tingkat vaksinasi dari orang tua anak rentan \\
$\varnothing(t)$ & Tingkat vaksinasi untuk anak-anak rentan tidak divaksin \\
$\rho(t)$ & Tingkat pulih setelah divaksin \\
\hline Parameter & Interpretasi \\
\hline
\end{tabular}




\begin{tabular}{cl}
\hline$\mu$ & Tingkat kematian alami \\
$\Lambda$ & Tingkat penularan \\
$f$ & Perbandingan bayi baru lahir yang rentan terhadap OPV \\
$\beta_{w}, \beta_{v}$ & Tingkat penularan \\
& Tingkat pertumbuhan dari $E_{w}\left(E_{v}\right)$ ke $I_{w}\left(I_{v}\right)$ \\
$\sigma_{w}\left(\sigma_{v}\right)$ & Tingkat kesembuhan dari infeksi WPV (VDPV) \\
$\psi_{w}\left(\psi_{v}\right)$ & Tingkat kematian akibat infeksi WPV (VDPV) \\
$\delta_{w}\left(\delta_{v}\right)$ & Tingkat kelumpuhan karena infeksi WPV (VDPV) \\
$\kappa_{w}\left(\kappa_{v}\right)$ & Parameter modifikasi \\
$\xi_{w}\left(\xi_{v}\right)$ & Perbandingan dari
\end{tabular}

Tabel 2. Nilai Koefisien dan Parameter

\begin{tabular}{clc}
\hline Parameter & \multicolumn{1}{c}{ Nominal values } & Dimension \\
\hline$\mu$ & 0.00001119 & $d a y^{-1}$ \\
$\Lambda$ & 441 & $d a y^{-1}$ \\
$f$ & $0.56[0,1]$ & \\
$\beta_{w}, \beta_{v}$ & {$[5,60]$} & $d a y^{-1}$ \\
$\alpha$ & $1 /(2 \times 360)[1 / 360,1 /(5 \times 360)]$ & $d a y^{-1}$ \\
$\phi$ & $(1 / 360)[1 / 360.1 /(3 / 360), 1 /(3 \times 360)]$ & $d a y^{-1}$ \\
$\rho$ & $(1 / 7)$ & \\
$r$ & $0.6[0,1]$ & $d a y^{-1}$ \\
$\sigma_{w}, \sigma_{v}$ & $(1 / 7)$ & $d a y^{-1}$ \\
$\psi_{w}, \psi_{v}$ & {$[1 / 16,1 / 35]$} & $d a y^{-1}$ \\
$\delta_{w}, \delta_{v}$ & $0,00003 / 360$ & \\
$\kappa_{w}, \kappa_{v}$ & $1 / 200$ & \\
$\xi_{w}, \xi_{v}$ & 1.5 & \\
$q$ & 0.00001 & \\
\hline
\end{tabular}

Matriks keterkontrolan diberikan sebagai berikut

$M_{C}=\left[\begin{array}{llllllllll}B & A B & A^{2} B & A^{3} B & A^{4} B & A^{5} B & A^{6} B & A^{7} B & A^{8} B & A^{9} B\end{array}\right]$

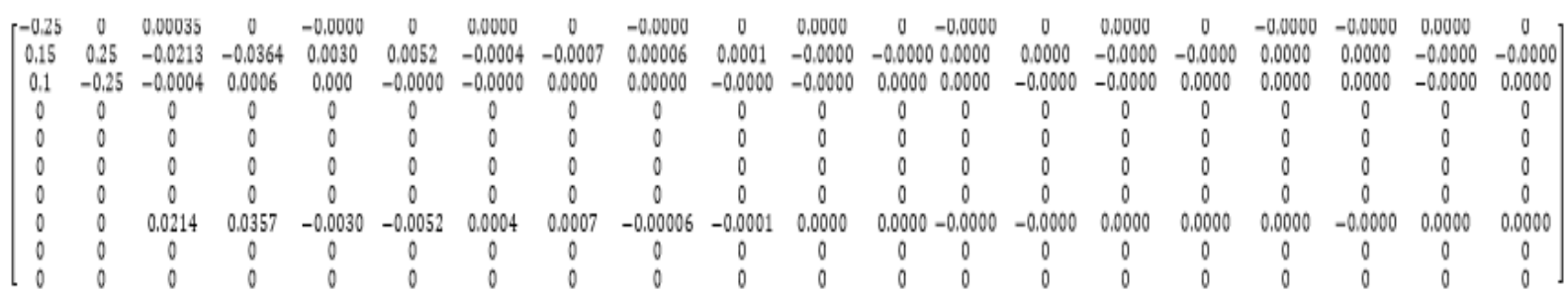

\section{Hasil dan Pembahasan}

Suatu sistem dikatakan terkontrol bila sebarang keadaan awal $x(0)$ dan sebarang keadaan akhir $x\left(t_{1}\right)$ akan selalu ada pengontrol $u(t)$ yang mentransfer keadaan awal $x(0)$ ke keadaan akhir $x\left(t_{1}\right)$ dalam waktu yang berhingga $t_{1}$. Sebarang keadaan awal dan sebarang keadaan akhir ini terdiri dari $n$ komponen 
dan jika semua komponen dari keadaan awal ini bisa dikontrol ke $n$ komponen yang sesuai keadaan akhir, maka system bisa dikontrol.

Keberadaan dari pengontrol $u(t)$ yang tak dibatasi tidak memiliki syarat kecuali hanya untuk mentransfer sebarang keadaan awal yang diberikan ke sebarang keadaan akhir yang diinginkan dalam waktu berhingga. Dengan kata lain suatu sistem dikatakan terkontrol ketika jumlah rank dari matriks keterkontrolannya sama dengan jumlah keadaan sistem tersebut.

Sebelumnya dilakukan uji keterkontrolan dengan menghitung jumlah rank pada sistem. Suatu sistem dikatakan terkontrol jika jumlah rank dari sistem sama dengan jumlah keadaan yang ada.

Matriks pada persamaan (1) merupakan matriks keterkontrolan dari sistem dinamik (2.1), suatu sistem dikatakan terkontrol ketika jumlah rank dari matriks keterkontrolannya sama dengan jumlah keadaan sistem tersebut (subiono, 2013). Dapat diketahui bahwa rank $(\mathrm{Mc})=10$ dengan jumlah keadaan adalah sepuluh.

Hal ini menunjukkan bahwa sistem dinamik dari dua tipe vaksinasi polio ini dapat dikontrol dengan variabel kendali yang diberikan yaitu (1) tingkat vaksinasi anak-anak rentan; (2) tingkat vaksinasi anak-anak rentan tanpa vaksin. Selanjutnya akan dilakukan pengendalian sistem tersebut dengan menerapkan pontryagin minimum principle (PMP) untuk mengetahui tingkat vaksinasi yang tepat pada populasi anak-anak sehingga dapat mengurangi tingkat terdampak dari kedua virus tersebut.

\section{Kesimpulan}

Hal ini menunjukkan bahwa sistem dinamik dari dua tipe vaksinasi polio ini dapat dikontrol dengan variabel kendali yang diberikan yaitu (1) tingkat vaksinasi anak-anak rentan; (2) tingkat vaksinasi anak-anak rentan tanpa vaksin. Selanjutnya akan dilakukan pengendalian sistem tersebut dengan menerapkan pontryagin minimum principle (PMP) untuk mengetahui tingkat vaksinasi yang tepat pada populasi anak-anak sehingga dapat mengurangi tingkat terdampak dari kedua virus tersebut.

\section{Daftar Pustaka}

[1] Brewster, J.F. dkk. 2006. Sensitivity and Uncertainty Analysis for SARS Model with Time Varying Inputs and Outputs, Mathematical Biosciences and Engineering, 3:3.

[2] Jennings, L.S., Fisher, M.E., Teo, K.L. dan Goh, C.J. 2002. Miser3 Optimal Control Software. Australia: The University of Western Australia.

[3] Naidu, D. S. 2002. Optimal Control Systems. USA: CRC Presses LLC.

[4] Okuonghae, D. dkk. "Dynamics of a two-strain vacconation model for polio”. Nonlinear Analysis: Real World Applications 25 (2015) 167-189.

[5] Subchan, S. dan Zbikowski, R. 2009. Computational Optimal Control : Tools and Practice. UK: John Wiley \& Sons Ltd.

[6] Subiono, 2013, Sistem Linier dan Kontrol Optimal, Diktat Kuliah Jurusan Matematika ITS, Surabaya. 
[7] Wiggins, S. 1990. Introduction to Applied Nonlinear Dynamical System and Chaos. New York: Springer-Verlag. 